\title{
INVESTMENT ATTRACTIVENESS OF THE PLANT EXTRACTS MARKET OF UKRAINE
}

\author{
${ }^{\circledR 2019}$ STEPANOVA A. A., PAVLENKO I. I.
}

UDC 330.3; 336.5; 338.4; 339.1

JEL: 013; Q13; Q17

\section{Stepanova A. A., Pavlenko I. I. Investment Attractiveness of the Plant Extracts Market of Ukraine}

Importance of the agro-industrial sector of Ukraine's economy can hardly be overestimated, because it is one of the largest and most significant pillars of development of the country's economy, where a significant share of added value is created and the bulk of the food resources is formed. It is also a sector that is export-oriented and determines the country's position in the international arena. The agro-industrial sector is also one of the most important elements of the economic systems of most market economies in the world. The high quality of national products and its eco-friendliness adequately occupy a niche in the European agricultural markets. However, the "white spots» in the development of certain areas of agro-industrial sector, which are being successfully developed by other countries, are worth noting. The article carries out a study on the investment attractiveness of a special sector in the agro-industrial complex of Ukraine - the market of plant extracts. The prospects and capital intensity of the plant extracts market are highlighted. The basic provisions for the definition and classification of plant extracts and spheres for their application are specified. The market of plant extracts has been allocated, the dynamics of export-import of plant extracts have been analyzed, and the tendencies of this segment of the agricultural sector have been defined. Researches and the global tendencies in development of the plant extracts market are considered and the basic provisions taking into account the Ukrainian characteristics are formed. Using the strategic management instrumentarium such as SWOT analysis, it has been demonstrated that the plant extracts market from a potential producer's perspective is promising and allows the development of a variety of business strategies to run own business taking into account available possibilities at the maximum. Directions of further development in terms of building own business in the market of plant extracts as a promising niche in the national economy are suggested. The positions of public policy for development of the plant extracts market are specified.

Keywords: the market's investment attractiveness, extract, agro-industrial complex, plant extracts market, SWOT market analysis. DOI: $h$ ttps://doi.org/10.32983/2222-4459-2019-12-171-177

Fig.: 6. Bibl.: 8

Stepanova Alla A. - PhD (Economics), Associate Professor of the Department of Management of Innovative and Investment Activities, Taras Shevchenko National University of Kyiv (60 Volodymyrska Str., Kyiv, 01033, Ukraine)

E-mail: ra_a@ukr.net

ORCID: $h$ ttp://orcid.org/0000-0002-1711-7948

Pavlenko Iryna I. - D. Sc. (Economics), Professor of the Department of Accounting and Taxation, European University (16-V Akademika Vernadskoho Blvd., Kyiv, 03115, Ukraine)

E-mail: pavlenko.iryna@yahoo.com

ORCID: http://orcid.org/0000-0002-5687-778X

УДК 330.3; 336.5; 338.4; 339.1 JEL: 013; 013; Q17

Степанова А. А., Павленко І. І. Інвестиційна привабливість ринку рослинних екстрактів України

Важливість агропромислового сектора економіки України важко переоцінити, адже це один з найбільших і найвагоміших стовпів розвитку економіки країни, де створюється вагома частка доданої вартості та формується основна частина продовольчих ресурсів. Окрім того, це сектор, який є експортоорієнтованим і визначає позиції країни на міжнародній арені. Агропромисловий сектор є також одним із найважливіших елементів економічних систем більшості країн світу з ринковою економікою. Висока якість вітчизняної продукції та ії екологічність достойно займають нішу на європейських ринках агропродукції. Однак варто відзначити «білі плями» в розвитку окремих напрямків агропромислового сектора, які успішно розвивають інші країни. У статті проведено дослідження інвестиційної привабливості саме такого сектора агропромислового комплексу України - ринку рослинних екстрактів. Висвітлено перспективність та капіталоємність ринку рослинних екстрактів. Зазначено базові положення щодо визначення та класифікації екстрактів рослинного походження та їх ссрер застосування. Виокремлено ринок рослинних екстрактів, проаналізовано динаміку експорту-імпорту рослинних екстрактів, визначено тенденцію розвитку даного сегмента аграрного сектора. Дослідження та враховано світові тенденції розвитку ринку рослинних екстрактів та сформовано базові положення з урахуванням українських особливостей. За допомогою використання такого інструментарію стратегічного менеджменту, як SWOT-аналіз, продемонстровано, що ринок рослинних екстрактів з позиції потенційного виробника є перспективним і дозволяє розробляти різні ділові стратегії для ведення власного бізнесу з максимальним урахуванням можливостей. Запро-
УДК 330.3; 336.5; 338.4; 339.1 JEL: 013; Q13; Q17

Степанова А. А., Павленко И. И. Инвестиционная привлекательность рынка растительных экстрактов Украины Важность агропромышленного сектора экономики Украины трудно переоценить, ведь это один из крупнейших и наиболее значимых столпов развития экономики страны, где создается значительная доля добавленной стоимости и формируется основная часть продовольственных ресурсов. Кроме того, это сектор, который является экспортоориентированным и определяет позиции страны на международной арене. Агропромышленный сектор является также одним из важнейших элементов экономических систем большинства стран мира с рыночной экономикой. Высокое качество отечественной продукции и её экологичность достойно занимают нишу на европейских рынках агропродукции. Однако стоит отметить «белые пятна» в развитии отдельных направлений агропромышленного сектора, которые успешно развивают другие страны. В статье проведено исследование инвестиционной привлекательности именно такого сектора агропромышленного комплекса Украины - рынка растительных экстрактов. Освещены перспективность и капиталоемкость рынка растительных экстрактов. Указано базовые положения по определению и классификации экстрактов растительного происхождения и их сфер применения. Выделен рынок растительных экстрактов, проанализирована динамика экспорта-импорта растительных экстрактов, определены тенденции развития данного сегмента аграрного сектора. Исследования и учтены мировые тенденции развития рынка растительных экстрактов и сформированы базовые положения с учетом украинских особенностей. С помощью использования такого инструментария стратегического менеджмента, как SWOT-анализ, продемонстрировано, что рынок растительных экстрактов с позиции потенциального производителя является перспективным и позволяет разрабатывать различные деловые стратегии для ведения собствен- 
поновано напрями подальшого розвитку в розрізі побудови власного бізнесу на ринку рослинних екстрактів як перспективної ніші у вітчизняній економіці. Зазначено позиції державної політики для розвитку ринку рослинних екстрактів.

Ключові слова: інвестиційна привабливість ринку, екстракт, агропромисловий комплекс, ринок рослинних екстрактів, SWOT-аналіз ринку. Рuс.: 6. Бібл.: 8

Степанова Алла Адамівна - кандидат економічних наук, доцент кафедри менеджменту інноваційної та інвестиційної діяльності, Київський національний університет імені Тараса Шевченка (вул. Володимирська, 60, Київ, 01033, Україна)

E-mail: ra_a@ukr.net

ORCID: http://orcid.org/0000-0002-1711-7948

Павленко Ірина Ігорівна - доктор економічних наук, професор кафедри обліку і оподаткування, Європейський університет (бульв. Академіка Вернадського, 16-В, Київ, 03115, Україна)

E-mail: pavlenko.iryna@yahoo.com

ORCID: $h$ ttp://orcid.org/0000-0002-5687-778X ного бизнеса с максимальным учетом возможностей. Предложены направления дальнейшего развития в разрезе построения собственного бизнеса на рынке растительных экстрактов как перспективной ниши в отечественной экономике. Указаны позиции государственной политики для развития рынка растительных экстрактов.

Ключевые слова: инвестиционная привлекательность рынка, экстракт, агропромышленный комплекс, рынок растительных экстрактов, SWOT-анализ рынка.

Puс.: 6. Библ.: 8.

Степанова Алла Адамовна - кандидат экономических наук, доцент кафедры менеджмента инновационной и инвестиционной деятельности, Киевский национальный университет имени Тараса Шевченко (ул. Владимирская, 60, Киев, 01033, Украина)

E-mail: ra_a@ukr.net

ORCID: http://orcid.org/0000-0002-1711-7948

Павленко Ирина Игоревна - доктор экономических наук, профессор кафедры учета и налогообложения, Европейский университет (бульв. Академика Вернадского, 16-В, Киев, 03115, Украина)

E-mail: pavlenko.iryna@yahoo.com

ORCID: http://orcid.org/0000-0002-5687-778X
$\mathrm{T}$ he scientific potential of a country is based on the current state of its economy and determines competitiveness of business entities. The path of innovative development of Ukraine requires considerable research, searching for new sources of investment and optimizing the structure of investments, primarily, in strategically important areas and s. Taking into consideration the fact that Ukraine has great potential in agriculture, there are strong arguments for attracting funds both Ukrainian and foreign investors, which will boost the competitiveness of business entities and the economy as a whole. Modern realities encourage enterprises and other organizations to find new ways, areas to ensure competitive advantages of their business activities. Indeed, embodying the latest investment projects can help overcome current challenges and gain advantages both in Ukrainian and international markets.

Cultivating plants and using Ukrainian raw materials to produce on their basis food, medical, cosmetic products, nutritional supplements (biologically active additives), etc., is one of the main prerequisites for the healthy functioning of the human body. The growing demand, favorable ecological and economic conditions for plant production positively influence the establishment and development of plant extracts market in Ukraine.

The aim of the article is to describe the investment attractiveness of the Ukrainian market for plant extracts.

Leading international organizations and agricultural holdings are engaged in investigating investment processes in the context of the sector under study [6]. The issues of stimulating investment activity to create a favorable investment climate and achieve the status of investment-attractive countries were considered by a number of scholars, including: G. Alexander, W. Behrens, J. Beily, L. J. Gitman, M. D. Joehnk, P. M. Hawranek, W. Sharp, K. E. Meyer, P. Sabluk, V. Andreychuk, I. Blank, T. Mayorova, A. Peresada, K. Savchuk, N. Khrushch, D. Chervanov, and others.
In the course of the research the following methods were applied: analysis and synthesis (to highlight contradictions in the agricultural sector), analysis of causal relationship (to identify the preconditions which formed in the crop production market), systems, historical and logical analysis (to identify the features of evolution of the relevant industry), graphical method (to illustrate the actual state of the investigated segment), various methods of statistical analysis. The information basis of the work is: monographs and periodical publications - both Ukrainian and foreign, Statistical Yearbooks.

$\mathrm{T}$ he agricultural sector of Ukraine with its main component - farming - is the basis and backbone of the national economy, creating factors of stability and independence of the country including food, economic, environmental and energy security. It ensures the development of technologically interrelated industries and promotes reliable and efficient functioning of the agricultural and food market of the country. It is this sector of Ukraine that is most attractive in the field of investment. It should be noted that in the majority of developing countries it accounts for about half of the GDP volume, and the employment in the agricultural sector exceeds 40\% [1]. Every year, the demand for agricultural products is growing, but not every country is doing everything it can to develop this sphere. In this sense, studying such a fairly narrow segment of the agroindustrial sector as the market for plant extracts is of interest. Currently, this segment is underdeveloped and largely import dependent. However, it has a great potential in the internal market, which, in the future, will provide for its entering international markets and exporting Ukrainian products.

The market for plant extracts is developing depending on the demand of the key industry consumers: manufacturers of nutritional supplements and medicinal plants, food, tobacco products and beer, cosmetic products. 
Extract (Lat. Extractum) is a concentrated substance made by extracting a part of a medicinal plant or animal material that is representing mobile, viscous liquid or dry material.

Liquid extracts are liquid concentrated substance extracted of medicinal plant materials (MPM) using ethanol or water in the ratio of 1:1. Pharmaceutical companies prepare liquid extracts by weight (from $1 \mathrm{~kg}$ of raw material $1 \mathrm{~kg}$ of liquid extract is obtained) [7] (Fig. 1).

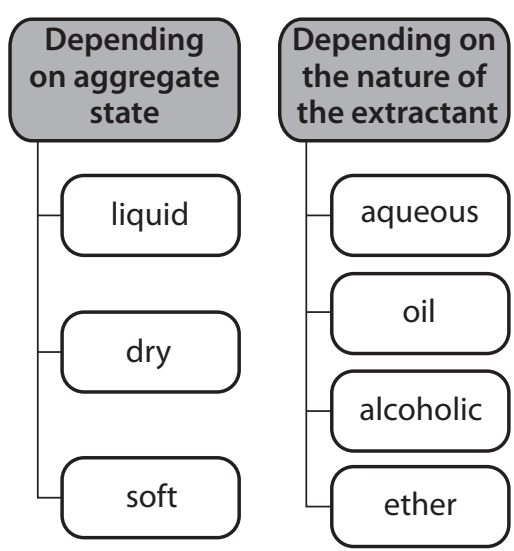

Fig. 1. Classification of plant extracts

Source: developed on the basis of [7].

$\mathrm{S}$ oft extracts are concentrated substance extracted of MPMs that presents viscous material with the moisture content of not more than $25-30 \%$. They cannot be poured out of the container, in an attempt to do so they stretch out in a thread and then merge into a solid mass again [7].

Soft extracts, due to their high viscosity, are used as binding form-building agents in the manufacture of pills. They also may be added as flavors to syrups, oral solutions, elixirs. Soft extracts are used as intermediates for a number of dosage forms (oral solutions, pills) [7].

Dry extracts are concentrated substance extracted of MPMs, which present the bulk material with the moisture content of not more than $5 \%$. They should be considered as the most rational type of extracts. They are easy to use and have the lowest possible weight [7].

Having analyzed government statistics on export/ import of plant extracts, we received the data confirming a significant share of imports in this segment (Fig. 2, 3).

The analysis of the size of investments for the past years shows that capital investment in agriculture increased from UAH 11.063 billion in 2010 to UAH 64.243 billion in 2017. Their share in the structure of capital investments increased from 6 to $14 \%$ respectively [3].

Taking into consideration the fact that the plant extracts have a wide range of application, the demand for various essential oils in the international market increases by $6-8 \%$ annually. It was forecasted that in five years following 2017, the market would grow from USD8 billion to USD12.1 billion (Fig. 4). About 50\% of the world's essential oil consumption accounts for Europe. The second place is taken by North America (26\%), the third one by Asian-Pacific region (24\%) [8].

$\mathrm{U}$ kraine, being close to the most receptive market for essential oils and having good conditions for medicinal plants cultivation, can make use this to increase the exports of this product. However, this potential has not been fully realized so far. On the contrary, the results of the first 11 months of 2017 demonstrate a decline in the production of essential oils in our country by almost $30.5 \%$, which happened due to a sharp rise in prices for imported raw materials [3].

However, the production of essential oils can be very beneficial, as evidenced by the example of Brazil, whose annual exports amounts to about 14.4 ths tons, or Germany -4.26 ths tons [8]. However, when organizing an enterprise specializing in production of essential oils in Ukraine, it is necessary to carefully choose the type of raw material, which will affect the output and cost of the final product. For example, a kilogram of dried lavender contains about two grams of oil, while lemon balm flowers - ten times less. Moreover, various types of raw materials may differ significantly from each other in price.

The approximate distribution of the initial investment can be as follows (Fig. 5).

As for medicinal plants, marketers note that the Ukrainian market for medicinal plants is estimated at UAH500 mln per year, with products worth UAH250 mln being exported mainly to the European Union market [4].

Compared to such giants as India and China, Ukraine's volumes are negligible since the capacity of the European market is estimated at 600 ths tons per year.

In Ukraine, about 25-30 species of medicinal plants are cultivated in commercial volumes. However, there are more than 6000 species on the territory of our country. Majority of them do not represent a commercial interest, some cultures are being harvested in the volume of 200-300 kg [1]. But there are those the demand for which on the market is measured in tons.

All this and the socio-economic situation are the confirmation of the instability of the market. The massive outflow of the labor force, which can actively be involved in this market segment, lack of leaders and the competition in the industry, as well as prospects for doing business under favorable economic and political conditions allow to speak about investment attractiveness of the plant extracts market and related areas.

We know that the purpose of any business is to maximize profits. Bringing a product / service to market the entrepreneur must be sure that consumers will buy it and it compares favorably with that of competitors. To succeed, it is necessary to have comprehensive information about the economic environment in which the business structure is operating or going to operate. This has contributed to the development of a tool for strategic analysis - SWOT analysis - from the perspective of a po- 


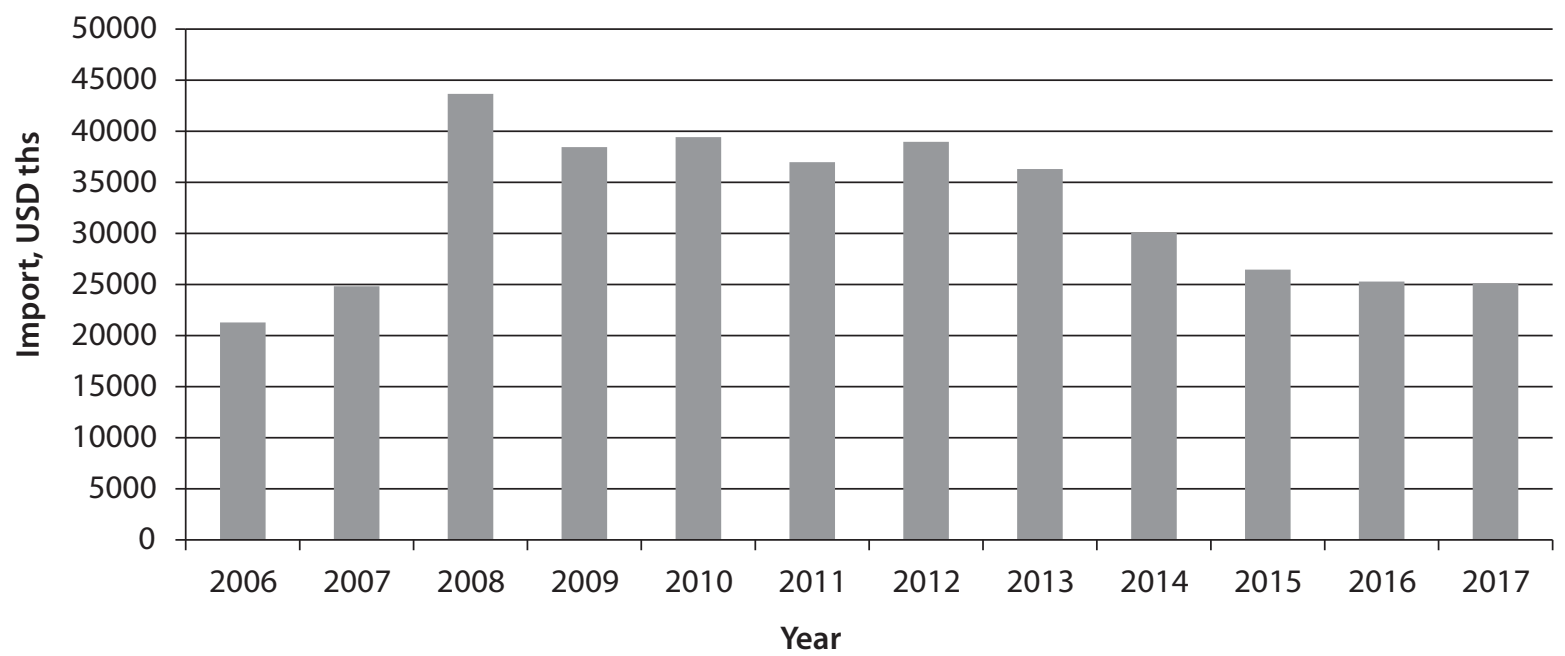

Fig. 2. Imports (Vegetable saps and extracts; pectic substances, pectinates and pectates; agar-agar and other mucilages and thickeners, whether or not modified, derived from vegetable products), USD ths

Source: developed on the basis of [3].

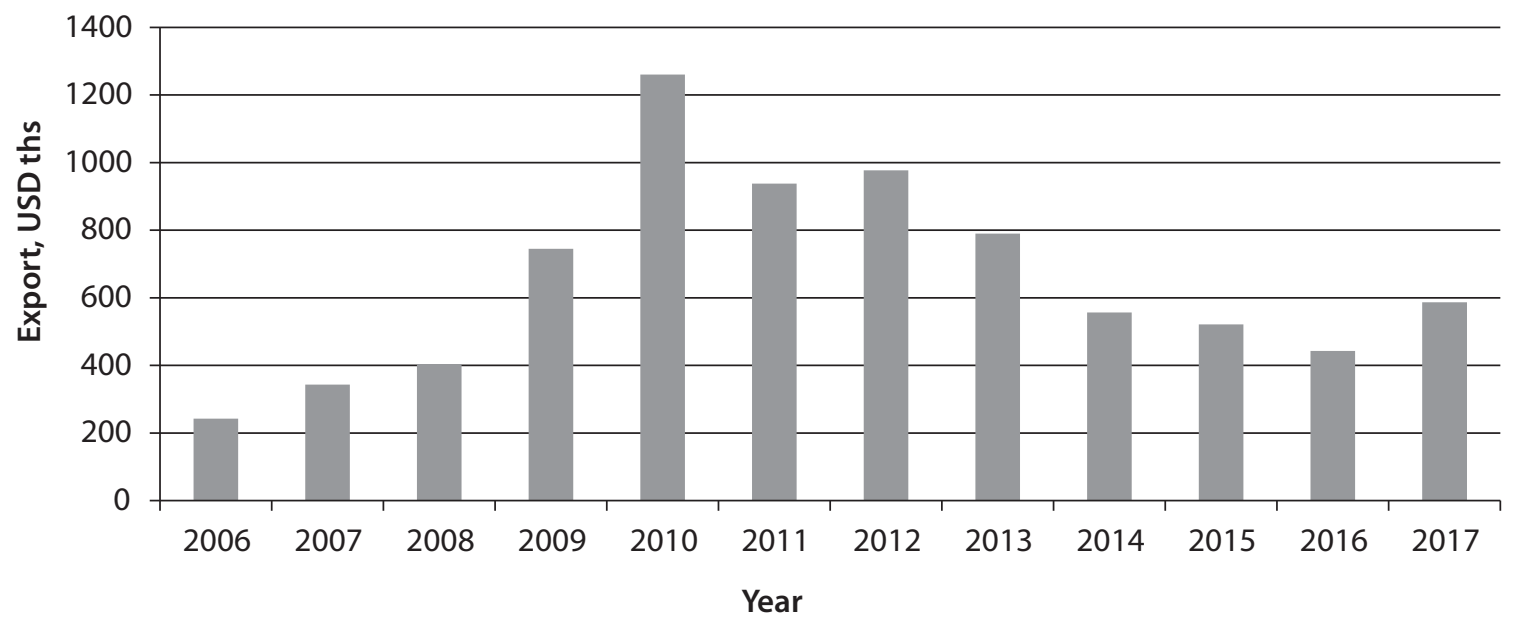

Fig. 3. Exports (Vegetable saps and extracts; pectic substances, pectinates and pectates; agar-agar and other mucilages and thickeners, whether or not modified, derived from vegetable products), USD ths

Source: developed on the basis of [3].

tential manufacturer of plant extracts. However, it is difficult to take into consideration or predict all conditions of the external and internal environment, therefore, this analysis needs further improvement (Fig. 6).

This matrix is combining all information on strengths and weaknesses of a manufacture, its opportunities and threats it can face. This makes it possible to form a certain strategy and direction for the company to achieve the most efficient results and remove potential obstacles.

Thus, SWOT analysis is important for determining competitiveness and investment attractiveness, as well as strategic planning since this method is an effective, intelligible, cheap way to evaluate the position of an enterprise in the market. It allows, through systemizing problematic situations, better understanding the structure of resources; tracking the overall state of the business environment; using new potential opportunities faster than competitors; choosing the best way for development and avoiding threats; making adequate decisions on the development of an enterprise. Today, correct and timely made strategic decisions play a key role in the success of an organization. They have a decisive impact on competitiveness of products, companies, and the market.

\section{CONCLUSION}

In general, the strategic objective of establishing and developing the plant extracts market is based on providing guaranteed and balanced cultivation, harvesting, processing medicinal plants, and supplying plant raw materials and extracts to various sectors of the national economy: pharmaceutical, baking, dairy, meat industries, industry of fruit and vegetable and fruit preserves, oil and fat production, confectionery, fish processing, perfume and cosmetic production, and other industries. However, in the absence of adequate government support for this kind of farming, agricultural producers are not interested in growing plants and their further processing. 


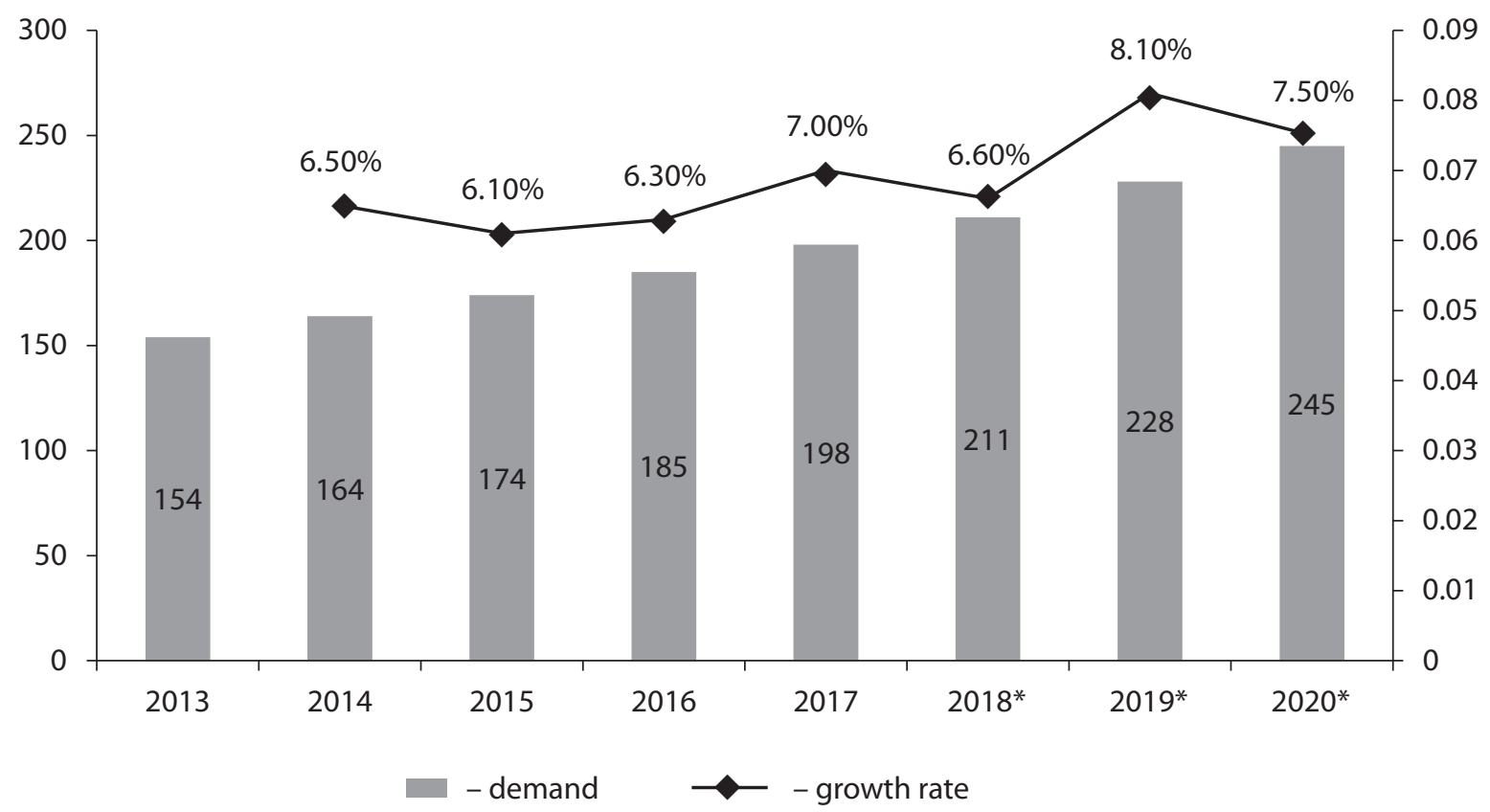

Fig. 4. Behavior of the global demand for essential oils, 2013-2020, ths tons

Note: * forecast period.

Source: developed on the basis of [8].

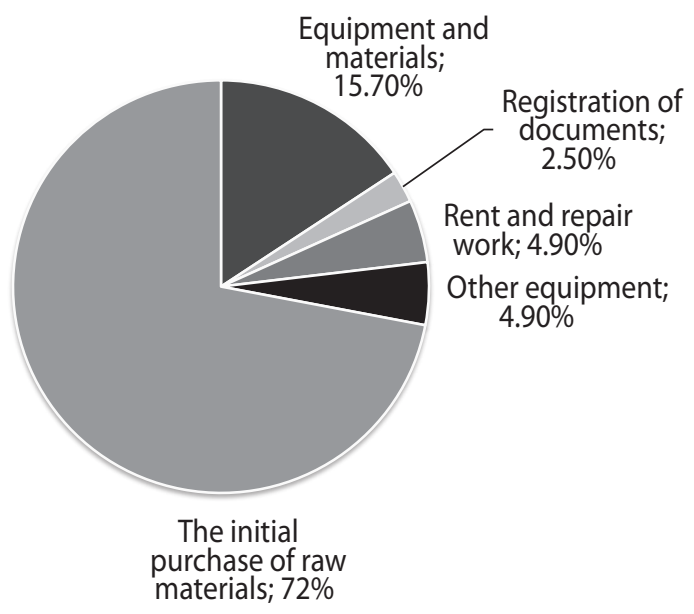

Fig. 5. Structure of initial investments for the following types of raw materials: lavender, mint, lemon balm

Source: developed on the basis of [2].

$\mathrm{T}$ To bring the agricultural sector to a new level and enhance its investment attractiveness, Ukraine will have to carry out long-term reforms in all relevant spheres - from harmonizing the legislation in line with European and international standards and creating transparent mechanisms for its implementation to developing infrastructure and entering new markets. As noted above, the potential of the Ukrainian agricultural sector is huge - the production volume can be three times higher [5]. This potential may remain as an estimated value of the existing capacity and powers of this sector of Ukraine's economy, but it can be realized as well. Of course, the second option is of priority; however, it is impossible to succeed without an active participation of investors, comprehensive investment proposals. Agri- culture needs funding, participating in joint specialized partner programs and involving international financial organizations in its financing.

\section{LITERATURE}

1. Дорош-Кізим М. М., Дадак О. О., Гачек Т. С. Перспективи розвитку агропромислового комплексу України в умовах євроінтеграції. Науковий вісник Львівського національного університету ветеринарної медицини та біотехнологій імені С. 3. ґжицького. 2017. № 76. Т. 19. С. 47-55. Doi:10.15421/nvlvet7610.

2. Головні аграрні новини. URL: https://agronews.ua

3. Офіційний сайт Державної служби статистики. URL: http://ukrstat.gov.ua

4. Офіційний сайт Секретаріату з підтримки експорту української продовольчої та аграрної продукції. URL: https:// ukrainefood.org

5. Пікулик О. І. Україна у світовому господарстві. Економіка і суспільство. 2018. № 15. С. 53-57. URL: http:// economyandsociety.in.ua/journal/15_ukr/9.pdf

6. Stepanova A., Horbas I., Davydova O. Practical Aspects of Strategic Marketing Management of Agricultural Enterprises (On the Example of "MRIYA AGRO HOLDING" LLC.). Фінансово-кредитна діяльність: проблеми теорії та практики. 2017. № 2. С. 221-228.

7. Технологія лікарських препаратів промислового виробництва / за ред. Д. І. Дмитрієвського. Вінниця : Нова книга, 2008. 280 c.

8. The Statistics Portal. URL: https://www.statista.com

\section{REFERENCES}

Dorosh-Kizym, M. M., Dadak, O. O., and Hachek, T. S. "Perspektyvy rozvytku ahropromyslovoho kompleksu Ukrainy 


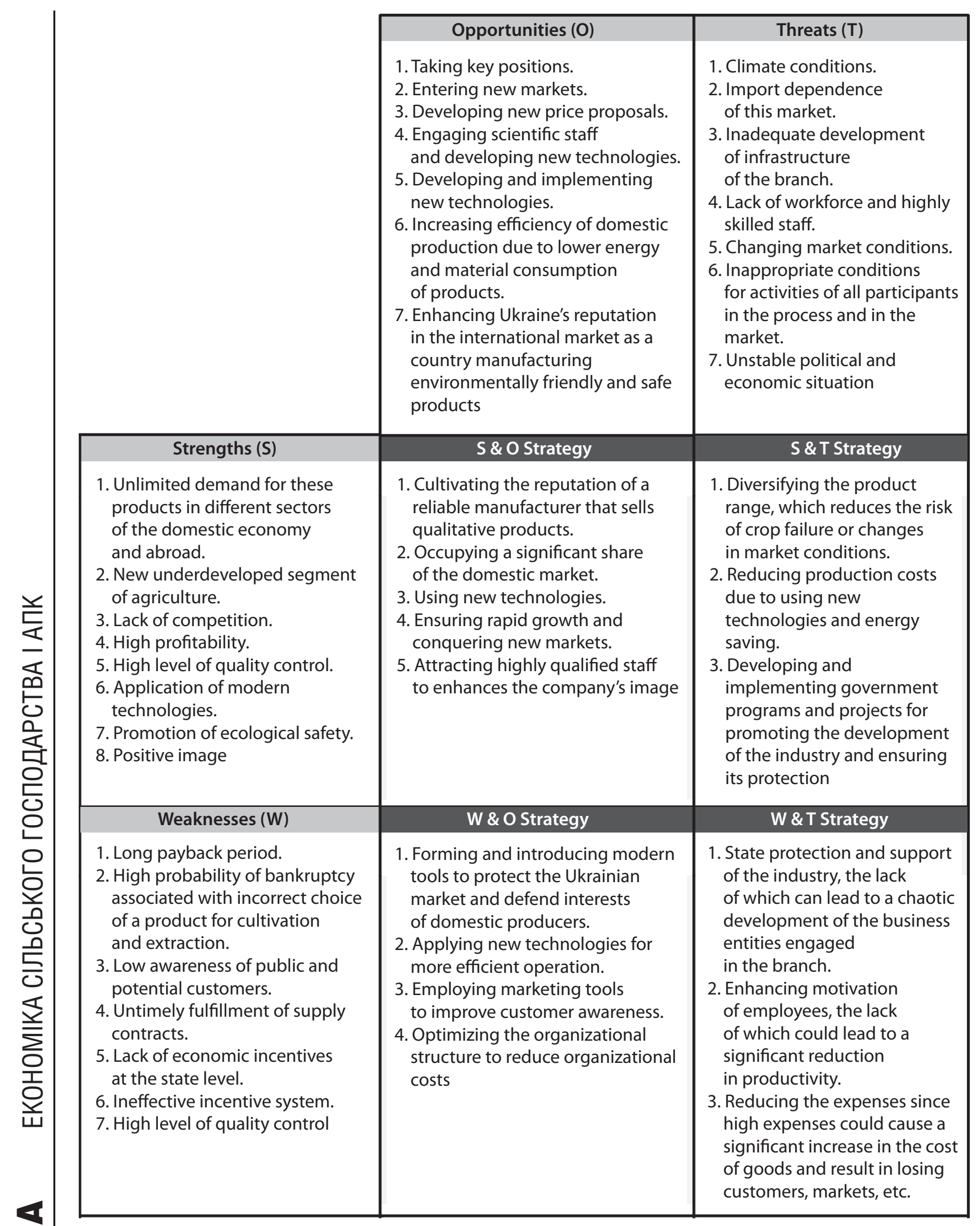

Fig. 6. SWOT correlation matrix of the plant extracts market from the prospective of a potential manufacturer Source: developed by the authors. 
v umovakh yevrointehratsii" [Prospects of Development of Agroindustrial Complex of Ukraine under Conditions of European Integration]. Naukovyi visnyk Lvivskoho natsionalnoho universytetu veterynarnoi medytsyny ta biotekhnolohii imeni S. Z. Gzhytskoho, vol. 19, no. 76 (2017): 47-55. Doi: 10.15421/ nvlvet7610

Holovni ahrarni novyny. https://agronews.ua

Ofitsiinyi sait Derzhavnoi sluzhby statystyky. http:// ukrstat.gov.ua

Ofitsiinyi sait Sekretariatu z pidtrymky eksportu ukrainskoi prodovolchoi ta ahrarnoi produktsii. https://ukrainefood. org
Pikulyk, O. I. "Ukraina u svitovomu hospodarstvi" [Ukraine in the World Economy]. Ekonomika i suspilstvo. 2018. http:// economyandsociety.in.ua/journal/15_ukr/9.pdf

Stepanova, A., Horbas, I., and Davydova, O. "Practical Aspects of Strategic Marketing Management of Agricultural Enterprises" [On the Example of "MRIYA AGRO HOLDING" LLC]. Finansovo-kredytna diialnist: problemy teorii ta praktyky, no. 2 (2017): 221-228.

Tekhnolohiia likarskykh preparativ promyslovoho vyrobnytstva [Technology of Medicines of Industrial Production]. Vinnytsia: Nova knyha, 2008.

The Statistics Portal. https://www.statista.com

\section{МОРСЬКІ КОНТЕЙНЕРНІ ПЕРЕВЕЗЕННЯ: СВІТОВІ ТЕНДЕНЦІї ○2019 ПЕТРЕНКО 0. I.}

JEL: L95

\section{Петренко О. І. Морські контейнерні перевезення: світові тенденції}

у статті досліджено стан та основні тенденції розвитку морських контейнерних перевезень у світі; проаналізовано динаміку та структуру морських контейнерних перевезень за регіонами світу, найбільшим серед яких є Азія; визначено динаміку контейнерних вантанопотоків та виділено 20 міст з найбільшим контейнерним вантажооборотом; визначено роль контейнерних перевезень у розвитку глобальної морської торгівлі. Встановлено, що обробка контейнерних вантажопотоків залишається зосередженою у великих портах. Загальна пропускна здатність 20 найбільщих портів світу зростає і у 2018 р. становила 347,8 млн TEU. Шанхай залишається найпотужнішим контейнерним портом у світі, найбільше зростання спостерігається в Сінгапурі. Лише п'ять портів за межами Азії представлені серед 20 провідних контейнерних портів, а саме: Антверпен, Гамбург, Лос-Анджелес, Лонг Біч та Роттердам. Очікується подальщий розвиток контейнерних перевезень з Китаю, що, своєю чергою, може спричинити скорочення обсягів та вантажопотоків на Транстихоокеанському маршруті. У морських контейнерних перевезеннях спостерігаються тенденції до створення альянсів між операторами терміналів, лінійними компаніями для спільної експлуатації причалів, що висуває нові вимоги до адаптації та технічної оснащеності портів. Вертикальна інтеграція та подальще розщирення транспортних ліній у термінальних операціях посилює конкуренцію між перевізниками. Встановлено, що розвитку морських контейнерних перевезень сприяє зростання економічної активності у світі, реструктуризація ланцюга поставок на користь великих суден і альянсів перевізників, цифровізація та модернізація транспортної інфраструктури, новітнє суднобудування, економічна інтеграція та інформатизація.

Ключові слова: морські контейнерні перевезення, світові контейнерні потоки, порт, обробка контейнерів, морський транспорт.

DOI: $h$ ttps://doi.org/10.32983/2222-4459-2019-12-177-184

Рис.: 2. Табл.: 2. Бібл.: 19.

Петренко Ольга Іванівна - кандидат економічних наук, доцент, завідувачка кафедри бізнес-логістики та транспортних технологій, Державний університет інфраструктури та технологій (вул. Кирилівська, 9, Київ, 04071, Україна)

E-mail: olga_co@meta.ua

ORCID: http://orcid.org/0000-0002-1869-7999

Researcher ID: http://www.researcherid.com/Q-8778-2018

$$
\text { УДК } 656.07
$$$$
\text { JEL: } L 95
$$

\section{Петренко О. И. Морские контейнерные перевозки:} мировые тенденции

В статье исследовано состояние и основные тенденции развития морских контейнерных перевозок в мире; проанализирована динамика и структура морских контейнерных перевозок по регионам мира, крупнейшим среди которых является Азия; определена динамика контейнерных грузопотоков и выделено 20 городов с наибольшим контейнерным грузооборотом; определена роль контейнерных перевозок в развитии глобальной морской торговли. Установлено, что обработка контейнерных грузопотоков остается сосредоточенной в крупных портах. Общая пропускная способность 20 крупнейших портов мира растет и в 2018 г. составила 347,8 млн TEU. Шанхай остается самым мощным контейнерным портом в мире, наибольший рост наблюдается в Сингапуре. Лишь пять портов за предела ми Азии представлены среди 20 ведущих контейнерных портов, а именно: Антверпен, Гамбург, Лос-Анджелес, Лонг-Бич и Роттердам. Ожидается дальнейшее развитие контейнерных перевозок из Китая, что, в свою очередь, может привести к сокращению объемов и грузопотоков на транстихоокеанском маршруте. В морских контейнер- 